\title{
DOHaD (Barker-hipotézis): egy betegségorientált, korszakalkotó, brit eredetü teória, magyar gyökerekkel
}

\author{
Csaba György dr.
}

Semmelweis Egyetem, Általános Orvostudományi Kar, Genetikai, Sejt- és Immunbiológiai Intézet, Budapest

\begin{abstract}
A „developmental origin of health and disease” (DOHaD-) teória 1986-ban jelent meg, összehasonlító epidemiológiai vizsgálatokkal bizonyítva a korai fejlődésben megmutatkozó kóros eltérések (például alul- vagy túltápláltság, csecsemőkori halálozás) statisztikai összefüggését felnőttkori nem kommunikábilis betegségek (például ischaemiás szívbetegségek, hypertonia) megjelenésével - és azóta széleskörúen elterjedt. A teória nagyon hasonló a hormonális imprinting koncepciójához, mely 6 évvel korábban jelent meg, és állatkísérletek alapján bizonyította a hormonszerü molekulákkal való perinatalis találkozás szerepét a felnőttkori endokrin és endokrin szabályozás alatt álló kóros jelenségek fellépésében. Ami mindkét teóriában azonos, az a perinatalis expozíció és a felnőttkori jelenség (betegség) összefüggése - ez az epigenetikai programozás zavarára utal. Barker a rendkívül fontos DOHaD-elmélet megalkotásakor már ismerte a hormonális imprintinget, amelyet a DOHaD lehetséges okának minősített, s ez bátoríthatta az elmélet kidolgozásakor. Barker szerint a DOHaD a nem fertőző betegségekre vonatkozik, de figyelembe véve, hogy a hibás hormonális imprinting az immunrendszer felnőttkori múködését is alapvetően és életreszólóan befolyásolja, lehetséges a fertőző betegségek, sőt az élettartam érintettsége is. A perinatalis időszakon kívüli kritikus periódus még a pubertás, amikor hibás átprogramozódás fordulhat elő, de bizonyos, folyamatosan differenciálódó sejtrendszerekben (például az immunrendszerben) a hibás imprinting felnőttkorban is létrejöhet. A két teória nem versenyez egymással, de eltérő módszereket alkalmazva és azonos következtetésre jutva kiegészíti és támogatja egymást, számos betegség epigenetikai magyarázatát (hibás átprogramozás) adva meg. A DOHaD és előzménye, a hormonális imprinting tehát nemcsak teóriák, de realitások, melyeket a diagnosztikában éppúgy, mint a terápiában ajánlatos figyelembe venni. Végiggondolva az emberi alkotótevékenység tendenciáit, a DOHaD (és a hibás imprinting) jelentősége a közeli és távoli jövőben várhatólag növekedni fog.
\end{abstract}

Orv Hetil. 2020; 161(16): 603-609.

Kulcsszavak: DOHaD, endokrin rendszer, magzati kor, hormonális imprinting, hibás imprinting, egyedfejlődés, epigenetika, fejlődési program, átprogramozódás

\section{DOHaD: a disease-oriented, epoch-making, British-originated theory with Hungarian roots}

On the basis of comparative epidemiological statistical studies, the 'developmental origin of health and disease' $(\mathrm{DOHaD})$ theory was published in 1986, testifying the interrelation between certain perinatal events, like under- and overfeeding as well as infant mortality with cardiovascular lethality in adults (Barker DJ, Osmond C, Lancet, 1986; 137: 1077-1081) - and at present it is widely extended. The theory is rather similar to the hormonal imprinting concept, which had been published 6 years earlier (Csaba G, Biol Rev Cambr Philos Soc. 1980; 55: 47-63 and Horm Metab Res. 1984; 16: 329-335). This demonstrated the role of perinatal encounter with hormones or hormone-like molecules with adult's endocrino-pathological events based on animal experiments. Barker hypothesized the role of hormonal imprinting in DOHaD (Phillips DI, Barker DJ, Osmond C, Acta Endocrinol (Copenh). 1993; 129 : 134-138: „A possible explanation is that thyroid hormones present in the breast milk and absorbed by the suckling infant could, by the process of hormonal imprinting, permanently down-regulate the set point of thyroid homeostasis", and this could have encouraged him to create the theory. Both theories suggest the relationship between the perinatal events and adult-age disease manifestation, however, in the case of faulty imprinting, perinatal disease does not have a role in the provocation by imprinters (only the encounter between the imprinter and the hormone receptor), but in the case of $\mathrm{DOHaD}$, this seems to be involved in the process. The whole process points to the disturbance of epigenetic programming. On the basis of the present standpoint, $\mathrm{DOHaD}$ is valid in non-communicative diseases, however, considering the impact of faulty hormonal imprinting to the immune system, the extension to communica- 
tive diseases is expected and likely also the involvement of lifespan. Further critical developmental period is the adolescence (puberty), when similar reprogramming could be possible and also in certain cases (e.g., in the immune system) disease-causing reprogramming could occur during the whole life. The two concepts are not racing, but using different methods for verification supplement and support each other, by building up identical conclusions (faulty reprogramming) giving epigenetical explanation for numerous diseases. DOHaD and its antecedent, hormonal imprinting are not only theories, but realities, which are commendable to consider in diagnosis and therapy. Studying the tendencies of human creativeness, in all probability, the importance of DOHaD (and faulty imprinting) will be growing in the near and far future.

Keywords: DOHaD, endocrine system, fetal period, hormonal imprinting, faulty imprinting, ontogeny, epigenetics, developmental program, reprogramming

Csaba G. [DOHaD: a disease-oriented, epoch-making, British-originated theory with Hungarian roots]. Orv Hetil. 2020; 161(16): 603-609.

(Beérkezett: 2019. december 21.; elfogadva: 2020. január 7.)

\section{Rövidítések}

DNS = dezoxiribonukleinsav; $\mathrm{DOHaD}=($ developmental origin of health and disease) felnőttkori betegségek méhen belüli eredete; RNS = ribonukleinsav

A múlt század vége felé David Barker angol epidemiológus megfigyelte, hogy van valamilyen összefüggés az alacsony születési súly, a születéskori soványság, az alacsony testméret, valamint a felnőttkori szérumkoleszterin-koncentráció, illetve az ezzel kapcsolatba hozható ischaemiás szívkárosodás és az ezáltal bekövetkező elhalálozás között (a sorozatban első közlemény [1] 1986-ban jelent meg). A cardiovascularis betegségben vagy 2 -es típusú diabetesben szenvedő felnőttek között nagyobb számban talált csökkent születési vagy csecsemőkori alultápláltságot (testsúlyt), mint az átlagpopulációban [2, 3]. De nemcsak az alultápláltság, hanem a csecsemőkori túlsúlyosság (túltápláltság) is vezetett felnőttkorban megjelenő betegségekhez. Így kimutatta, hogy 5585 nő közül, akik egy bizonyos körzetben (Hertfordshire) születtek, az a 4l, aki petefészekrákban halt meg, túlsúlyos volt csecsemőkorában [1]. Arra is felfigyelt, hogy Angliában és Wales-ben összefüggés van a csecsemőhalálozási ráta és a felnőttkori ischaemiás halálozási ráta között [1]. Összefoglalóan, Barker epidemiológiai statisztikai összehasonlító vizsgálatok eredményeként a magzati alulvagy túltápláltságot ismerte fel felelősként ezen felnőttkorban „spontán” jelentkező nem fertőző betegségekért $[1,3,4]$. Később a megfigyeléseket általánosította, és feltételezte, hogy a felnőttkori nem fertőző betegségek fellépése, illetve elmaradása általában összefügg a perinatalis állapottal, azaz a felnőttkori, rendszerint krónikus betegségek fellépése a magzati kori állapottal (ártalmakkal) magyarázható - a programozásnak egy olyan zavara, mely hosszú távon, akár évtizedekkel a magzati provokáció után mutatkozik meg [5]. A jelenség egzakt magyarázatát (mindmáig) nem tudták megadni, de egyik lehetséges magyarázatként elfogadták a hormonális imprin- tinget [6], mely magyar kutatók állatkísérleti megfigyelésein alapult $[7,8]$, bizonyítva, hogy a fejlődő hormonreceptor és a célhormon perinatalis kritikus periódusban való találkozása életreszólóan bevésődik az epigenetikai programba. Barker és mtsai a csecsemókori, illetve fetalis táplálkozás felnőttkori hatását állatkísérletekben is igazolták és általánosították [9]. Így született meg a DOHaD (developmental origin of health and disease) teóriája, mely relatíve rövid idő alatt szédületesen sikeres pályát futott be: nemcsak rengeteg tudományos dolgozat foglalkozik a témával, de létrejött egy nemzetközi DOHaD Társaság, mely 2019-ben már a 11. kongresszusát tartotta (több mint 1000 résztvevővel) az ausztráliai Melbourne-ben, és a nemzeti tudományos DOHaD-társaságok mellett a Nemzetközi DOHaD Tudományos Társaság, valamint kutatóintézet és folyóirat viseli a DOHaD nevet. Nem érdemtelenül: a DOHaD teljesen új szempontból vizsgálja és magyarázza a nem fertőző betegségek fellépését, miközben korunkban ez utóbbiak jelentősége - részben az emberi élettartam meghosszabbodása, részben a kiváltó tényezók számbeli és minőségbeli növekedése miatt - egyre inkább előtérbe kerül. Egyre-másra sorolódnak be az eddig jórészt ismeretlen etiológiájú betegségek a DOHaD által kiváltottak közé, és sorolódnak át az eddig ismertnek hitt (félreismert) betegségek a DOHaD által kiváltottak tömegébe. Feltétlenül érdemes, sőt szükséges megismerkedni a DOHaD-dal mint olyan kórokozó folyamattal, amelyet látszólag végzetszerúen hoz magával az ember, és azokkal a tényezőkkel, amelyek a megnyilvánulását lehetővé teszik.

\section{A fejlődési program és az átprogramozódás (reprogramming)}

Minden élőlény rendelkezik egy génkészlettel, melyben különböző funkcióval rendelkező gének találhatók. Vannak, melyek meghatározzák a fajt (ember) vagy a 
rasszt (például: ázsiai), míg mások bizonyos, az adott fajra jellemző alapvető funkciókat határoznak meg (háztartási gének, melyek az adott faj minden egyedében jelen vannak, és például az anyagcserét, sejtlégzést stb. szabályozzák) - ezek az adott faj minden egyedének minden sejtjében azonosak. Végül vannak olyan gének, melyek - legalábbis szabályozásukat tekintve - egy adott egyedre, illetve szervre (sejtre) jellemzőek, tehát egy adott egyeden belül is különbözőek, például attól függően, hogy a retinában vagy a májban találhatók. A gének múködése meghatározott program szerint van elrendezve, és a program határozza meg a gén múködését (mikor és hogyan). A program végrehajtása serkenthető és gátolható: transzkripciós faktorok serkentik, és metilcsoportok (a promoterhez kapcsolódva) gátolják a génekben lévő információ átadását. A születéskor már jelen lévô program átalakul és átalakítható az élet folyamán. Vannak kritikus fejlődési periódusok, mint a perinatalis időszak (fetalis, praenatalis, korai postnatalis periódus), éppúgy, mint az elválasztás és a pubertás időszaka, amikor nyitva van a fejlődési ablak, és ilyenkor nemcsak lehetséges az átprogramozódás, de ez szervezeti igényként lép fel. Átprogramozódás után már az új (megváltozott) program érvényesül mindaddig, amíg - esetleg - újabb átprogramozódás nem történik. Miközben vannak olyan szervek, amelyekben a program stabil (például az idegrendszer egyes funkcióira vonatkozóan vagy a mozgásrendszerben), vannak olyan szervrendszerek (szervek, sejtek), melyek az átlagosnál érzékenyebbek az átprogramozódásra (például az immunrendszer), melyben a sejtek differenciálódása az egész élet folyamán tart és teremt lehetőséget az átprogramozódásra, míg más szervek, szervrendszerek esetében az utolsó átprogramozódási lehetőség a pubertás időszakában van.

A program kialakításában, illetve átalakításában (reprogramming) egy teljes rendszer vesz részt: metilációs enzimek (DNS-metiltranszferáz-1 a metilációs mintázat kialakításához és DNS-metiltranszferáz-2 a metilációs mintázat fenntartásához), valamint demetiláz(ok) a metilációs mintázat eltávolításához (törléséhez), hisztonacetiláz, nem kódoló RNS-ek stb. A mintázat átörökítéséhez szükség van az ivarsejtek közremúködésére, akár anyai, akár apai ágon. Az eredeti vagy már átprogramozott metilációs mintázat nagy része törlődik az új egyed fejlődésének kezdeti szakaszaiban, de egy részük rezisztens, és fennmarad, azaz átkerül az utódgenerációra, és ez biztosítja a programban lévő új információk átörökítését. Ez azt is jelenti, hogy egy-egy betegség előfordulásának növekvő számában nemcsak az újonnan provokált betegségek vesznek részt, hanem az örökletesen meglévők is.

A fentebb említettekből következik, hogy a DOHaD a programozás olyan zavara, amelyet valamilyen fiziológiás (például táplálkozási) tényező abnormális irányba való eltolódása válthat ki, és amelynek következményei hoszszú távon, akár évtizedek elteltével mutatkoznak meg, éppen ezért a közvetlen összefüggés bizonyítása nehéz, de a közvetetté nem lehetetlen, mint ezt éppen Barker megfigyelései bizonyítják.

\section{A fiziológiás és kóros (hibás) hormonális imprinting}

A múlt század hetvenes éveiben végzett állatkísérletekben figyeltük meg, hogy a célhormonnal való első találkozás után, az újabb találkozások alkalmával a hormonreceptorok kötési képessége megváltozott, és ez az adott hormonra kialakuló sejtválaszban is megmutatkozik. A sejt mintegy memorizálta a hormonnal való első találkozást [10], azaz átprogramozódott. Ezt a jelenséget nevezte el a szerző az 1980-ban megjelent összefoglaló cikkében [7] hormonális imprintingnek. Kiderült az is, hogy ez biológiai alapjelenség, amely már az egysejtü Tetrahymenában is megfigyelhető, tehát az evolúció korai szakaszában éppúgy megtalálható, mint a magasabb rendü emlősökben [11]. Valószínünek tünik, hogy egysejtúben segíti az életben maradást, amikor az idegen molekula már alacsonyabb koncentrációban is jelzi az esetleg veszélyes anyag jelenlétét, míg az evolúció magasabb szintjein, ahol már endokrin rendszerről beszélhetünk, hozzájárul a hormonok biztosabb felismeréséhez.

A hormonális imprinting magasabbrendűekben a fejlődési program kialakulásának részjelensége, amely döntően a fejlődő hormonreceptor és a célhormon első találkozása alkalmával jön létre. Ez feltétlenül szükséges a receptor-hormon kapcsolat normális és élethosszan tartó kialakulásához, éppen ezért rendszerint a perinatalis időszakra esik. A hibás hormonális imprinting valószínüleg káros „melléktermékként” jelent meg az evolúció alatt, és vált fontossá kémiailag erősen „fertőzött” modern korunkban mint az átprogramozódás részjelensége. Átprogramozódás alkalmával a receptor-hormon kapcsolat ugyancsak élethosszan megváltozik. A hibás imprinting a receptor kötési-felismerési képességének megváltozásában mutatkozik meg, és egyrészt élethosszan fennmarad, másrészt epigenetikusan (a DNS bázissorrendjének megváltozása nélkül) sejtrôl sejtre öröklődik. A fiziológiás átprogramozódás tehát szükséges, és ezt a fiziológiásan jelen lévő hormonok végzik el, tekintettel azonban arra, hogy végbemeneteléhez a fejlődési ablak nyitva tartása szükséges, a fiziológiás hormonokhoz hasonló molekulák (endokrin disruptorok, melyek ugyancsak felismerésre kerülnek a fejlődő receptorok által) is megteszik, és ez hibás imprintinget alakíthat ki. A hibás imprinting funkcionális teratogén $[12,13]$, azaz morfológiai (szomatikus) változás nélküli funkcionális zavart hoz létre, amely - szemben a morfológiai teratogenitassal (torzképződéssel) - születéskor nem feltúnő, de bármely további életszakaszban enyhébb vagy súlyosabb funkcionális eltéréssel jelentkezik. Míg a szomatikus teratogének a legintenzívebben a korai (embrionális) periódusban fejtik ki hatásukat, addig a hibás imprinterek elsősorban a fetalis időszakban, tehát praenatalisan, 
de hatástartományuk kiterjed a korai postnatalis (perinatalis) időszakra is, ami azt jelenti, hogy a funkcionális teratogenitas nem fejeződik be a születéssel, hanem azután is tart. Mivel nem időszakfüggő, hanem egy adott időszakban éppen differenciálódó sejtekre hat, jellemző a csecsemő elválasztási időszakára, de a pubertásra is, illetve egyes szervrendszerekben az egész élet folyamán tart [14-16]. Ez utóbbi jellemző például az immunrendszerre, melynek sejtjei állandóan differenciálódnak, így az idős immunrendszer is imprintálható [14-16]. A betegségek szempontjából mégis a perinatalis és a serdülőkori hibás imprinting látszik a legfontosabbnak, jelentős és hosszan tartó következményei miatt.

\section{Hasonlóságok és különbségek a hormonális imprinting és a DOHaD között}

Barker és mtsai szerint a hormonális imprinting a DOHaD lehetséges közvetítő mechanizmusa [6], ugyanakkor valószínúnek tünik, hogy a két jelenség lényegében azonos. Mindkettő esetében egyedfejlődés alatti behatás mutatkozik meg késői (felnőttkori) időszakban [17]. A különbség - ha feltételezzük, hogy ilyen valóban van - abban mutatkozhat meg, hogy a DOHaD szélesebb körü, míg a hormonális imprinting célzottan a hormonális hatásra vonatkozik, bár újabban nem-hormon gyógyszerek esetében is kimutatható volt [18, 19]; figyelembe veendő azonban, hogy a $\mathrm{DOHaD}$ esetében is van hormonális közremúködés, és a (hibás) hormonális imprinting vagy a fiziológiás imprinting elmaradása is késői betegségek manifesztációjához vezet, éppúgy, mint a DOHaD. Míg a hormonális imprinting esetében állatkísérleti (hormon-receptor kötési) eredmények értékelése vezetett el a teóriához (a hormonális imprinting létezéséhez és jelentőségének értékeléséhez), addig a DOHaD esetében epidemiológiai statisztikai analízis, a fenőttkori kórképek és a korai állapotok egybevetése. A módszerbeli különbségek mellett a következtetések azonosak, és egymást támasztják alá: egyaránt bizonyítják az összefüggést a perinatalis kori állapot (például alultápláltság) vagy beavatkozás (például hormonszerü molekulák - endokrin disruptorok - jelenléte) és a beavatkozás kiváltotta felnőttkori kóros állapot között. Ugyanakkor a különbség abban mutatkozhat meg, hogy míg a DOHaD esetében egy korai kóros állapot (például alultápláltság) teremti meg a felnőttkorban jelentkező kóros állapot alapját, addig a hibás hormonális imprinting esetében nincs perinatalis kóros állapot, csak valamely megnevezhető hormonszerü molekula, s az azzal való akár egyszeri találkozás kiváltja a felnőttkori eredményt [20-27].

A sejtvonalban való, illetve traszgenerációs öröklődés is egyaránt jellemző mindkét koncepcióra. Ahogy emlőskísérletekben megfigyelhető, a hormonális imprinting öröklődését a 3. generációig bizonyították (tovább nem vizsgálták, mert ritka a generációváltás), azonban az egysejtú Tetrahymenában, amelynél gyors a generációváltás, még az 1000-dik generációban is megfigyelhető volt.
Emlősökben és emberben a DOHaD öröklődése is megfigyelhető $[28,29]$. Ez érthető, mivel az imprinting és a DOHaD esetében egyaránt átprogramozódás történik, és ennek eredményeként jelenik meg a felnőttkori betegség. A legnagyobb különbség mégis abban rejlik, hogy a jelenlegi álláspont szerint $\mathrm{DOHaD}$ esetében a magzati kori kóros állapot van összefüggésben a felnőttkori betegséggel (és éppen ez volt Barker megfigyelésének alapja), míg a hormonális imprinting koncepciójának esetében nem figyelhető meg magzati kori betegség, csak az imprinter általi provokáció (reprogramming, amely nem látható) történik meg, s ennek eredménye a késői betegség, mely viszont mindkét esetben fellép és észlelhető.

A DOHaD és a hibás hormonális imprinting olyan betegségek fellépését magyarázza meg, amelyek mostanáig is ismertek voltak, csak kórokuk volt ismeretlen. Tehát nem új kórképekről van szó, hanem régen ismert kórképekról, melyek oka ismeretlen vagy félreismert volt, illetve a feltételezett okok között nem szerepeltek epigenetikai jelenségek, tehát génszabályozási hibák. Jelenleg is nehéz bizonyítani az összefüggést valamely több évtizeddel ezelőtti történés és annak távoli következményei között, legfeljebb állatkísérletek szolgáltathatnak bizonyítékot, melyek azonban csak hasonlóak az emberi történésekhez. Ez azonban minden olyan esetben fennáll, amikor egy gének által meghatározott ritka tulajdonságról, illetve annak zavaráról van szó. Nyilvánvaló például, hogy a mûvészi (például festőművészi) képesség génszinten meghatározott, de csak akkor tudjuk, hogy létezik, ha múvekben manifesztálódik, e nélkül nem tudunk a létezéséről. Ugyanez vonatkozik a DOHaD által meghatározott betegségre is, azaz a program zavara csak akkor diagnosztizálható, ha a programban a normálvariáns megjelenésére való utasításnak eljött az ideje, és megjelenik a mú, amely ebben az esetben egy adott betegséget jelent. Ennek lehet a programban meghatározott ideje (például a pubertás), de lehet egy külső provokátor (például valamilyen anyag vagy terhelés, illetve hiány) következménye. Az előbbi esetében az hihető, hogy spontán lépett fel a kór, az utóbbi esetében a provokátort okoljuk, és nem vesszük figyelembe a perinatalis előzményeket, pedig ezek szolgáltatják az alapot a betegség manifesztációjához. A provokátor csak akkor múködik, ha az epigenetikai alapok rendelkezésre állnak, azaz aktiválja a programban a hibás (átprogramozott) géneket.

\section{Betegségek, melyek a DOHaD-dal magyarázhatók}

Barker és Osmond a Lancet folyóirat egyik 1986. évi számában közölte a cikket, melyben beszámoltak megfigyelésükról: e szerint Anglia és Wales egyes vizsgált körzeteiben az ischaemiás szívbetegek 1968 és 1978 közötti mortalitása szoros összefüggést mutat az 1921 és 1925 közötti csecsemőhalálozással. Feltételezték, hogy a szívbetegek halálozása visszavezethető perinatalis táplálkozási ártalmakra (alultápláltság) [1]. Hasonló összefüg- 
gést találtak bronchitis, gyomorrák és reumatikus eredetú szívhalálozás és a csecsemőhalálozás között. Ezzel a felismerésükkel egy új etiológiai tényezőt emeltek be az orvosi tudatba, és elindult a DOHaD azóta is sikeres menetelése.

Az azóta eltelt 34 év alatt még számos betegség került be a $\mathrm{DOHaD}$ által kiváltottak kategóriájába. Ilyen a hypertonia és a stroke, a túlsúlyosság (obesitas) és velejárói, a 2-es típusú diabetes, a hyperglykaemia és a hyperinsulinaemia, valamint számos elmebetegség, mint például a bipoláris elmezavar, a depressziók és a skizofrénia [30]. De nem maradhattak ki a különböző rákos és reprodukciós kórképek, valamint a pajzsmirigy betegségei sem [24].

Nagyon valószínúnek tünik, hogy ez a felsorolás vagy bármilyen más (jelen vagy jövő idejű) felsorolás hiányos, mert a DOHaD, éppúgy, mint a hormonális imprinting, sokkal szélesebb körben jár következményekkel, mint amit egy felsorolásban ismertetni helyes, és jelenlegi álláspontunkat az befolyásolja, hogy mit vizsgáltak egyáltalán, és mit nem. Ugyanakkor a DOHaD és a hormonális imprinting lehetséges hatásait mindenhol figyelembe kell venni, akár van rájuk vonatkozó konkrét adat, akár még nincs, és itt a „még”-en van a hangsúly. Valószínú, hogy az a megszorítás, amely szerint a DOHaD csak a nem kommunikábilis betegségekre vonatkozik, sem állja meg a helyét, mert az immunrendszer rendkívül átprogramozásérzékeny, ennek következtében a DOHaD (és a hormonális imprinting) a fertőző betegségek fellépését és lefolyását, valamint az élettartamot is befolyásolja.

\section{A DOHaD és a pubertás}

Vannak feltételezések, amelyek szerint a DOHaD-teória nemcsak perinatalisan érvényes, hanem egyéb kritikus periódusokban is, így például a serdülőkorban [31, 32]. Ezt korábbi, hibás imprintinggel kapcsolatos állatkísérleti vizsgálataink már bizonyították [33]. A serdülőkori hatás öröklődésére is van példa [34]. Úgy túnik tehát, hogy a DOHaD-ra lényegében ugyanazok a törvényszerüségek érvényesek, amelyek a hormonális imprintingre is: nem a behatás időpontja lényeges, hanem az átprogramozódás lehetősége.

\section{A DOHaD és a hormonális imprinting jövője}

Megkockáztatható annak kijelentése, hogy a statisztikai adatokból leszürt zseniális meglátáson kívül a hormonális imprinting ismerete is hozzájárult a $\mathrm{DOHaD}$-elmélet kialakításához. A hormonális imprinting összefoglaló alapcikke, melyben már ez a név is szerepelt, 1980-ban jelent meg [7], tehát hamarabb, mint a DOHaD alapcikkei (1986-tól). David Barker ismerte is ezt a cikket, amelyet, bár nem idézett, de egyik, pajzsmiriggyel kapcsolatos fontos írásában [6] a hormonális imprintingnek a DOHaD-ban való részvételét így minősíti: „a possible explanation is that thyroid hormones present in breast milk and absorbed by the suckling infant could, by the process of hormonal imprinting, permanently down-regulate the set point of thyroid homeostasis", és egy másik alapvető cikkében [34] két hormonális imprintinges cikket $[35,36]$ is idéz.

Több részcikk után, melyekben még receptormemóriaként szerepelt a hormonális imprinting, az alapcikk 1980-ban a Biological Reviews of the Cambridge Philosophical Society-ban jelent meg [7], mely magas impaktfaktorú folyóirat volt (most is 10 felett van), ennek ellenére nem váltott ki akkora érdeklődést (mindmáig), mint Barker és Osmond cikke a Lancetben [1] - ez érthető, ha figyelembe vesszük ez utóbbi folyóirat gyakorló orvosok általi olvasottságát, emberközpontúságát és a Barker-cikk gyakorlati szempontból való hasznosságát, valamint a Biological Reviews biológiai célközpontúságát éppúgy, mint az állatkísérletekből (!) levont következtetéseket.

A DOHaD, vagy ha úgy tetszik, a hormonális imprinting, sok betegség fellépésére magyarázatul szolgálhat. Nem látszik ugyanis véletlen jelenségnek bizonyos nem fertőző betegségek járványszerű (tömeges) fellépése, amely korunkra jellemző. Ha a bakteriális vagy vírusos fertőzés kizárható, akkor ennek oka a környezetben kereshető, illetve olyan tényezőkben, amelyek korábban nem voltak jellemzőek, és amely tényezőkre az emberi szervezet nem volt felkészülve, illetve a velük való együttélést nem tolerálja. Ezek a tényezők lehetnek nem nevesített táplálkozási faktorok, illetve mennyiségi tényezők, mint amelyeknek az egyedfejlődés alatti szerepét éppen Barker helyezte előtérbe, amikor az alul- vagy túltápláltság szerepét hangsúlyozta, de lehetnek endokrin disruptorok, melyeknél a minőségi hatás dominál. Mindkettő korunk terméke, amennyiben megváltoztattuk a kritikus periódusokban a táplálkozási szokásokat, illetve tömegesen olyan, ember teremtette anyagokkal hoztuk érintkezésbe a fejlődő magzatot (és serdülőt), melyek strukturálisan és/vagy funkcionálisan utánoznak bizonyos, fiziológiásan jelen lévő molekulákat, ezek receptoraikhoz kötődnek, ezáltal hibás információkat továbbítanak, ami a fejlődési program tartós megváltozásához vezet. Míg a DOHaD-teória a kórosnak tekinthető magzati állapotokra helyezi a hangsúlyt a felnőttkori betegség okaként [37], addig a hormonális imprinting koncepciója a kémiai faktorokra, melyek a környezetünkben, ebből következőleg az anya vagy a magzat, serdülő stb. szervezetében feldúsuló idegen molekulákra (endokrin disruptorokra) [38]. Ez azt jelenti, hogy a DOHaD esetében korábban is meglévő (nagyobbára ismeretlen) tényezők vádolhatók a felnőttkori betegségek megjelenése miatt, míg a hormonális imprinting inkább a modern korunkra jellemző, ember teremtette molekulákra helyezi a hangsúlyt. Ha a DOHaD-koncepció ezen oldalát vesszük figyelembe, a nem fertőző betegségek számának növekedése nem várható. Ha a hormonális imprinting koncepciójának ezen oldalát vesszük figyelembe, a nem fertőző 
betegségek jelentős mennyiségi növekedése várható, miközben a fertőző betegségek mennyisége csökken. Ebben az esetben tehát a két koncepció általi előrejelzés ellentétes, és az imprinting koncepciója előrejelzésének eredménye inkább várható.

Jelenleg a program megváltozása irányítatlan, és hiba hibára halmozódik, annál is inkább, mert - mint láttuk az átprogramozódás nemcsak az adott sejtvonalon belül, hanem transzgenerációsan is öröklődik. Mivel az emberi alkotótevékenyég nem áll le, sőt szükségszerüen helyettesíti a biológiai evolúciót $[39,40]$, a jövőben a hibás imprintinget kiváltó molekulák mennyisége és variabilitása még nőni fog. Lehet, hogy az elhárításukra alkalmazott kémiai termékek egyes károsító tényezőket valóban kiiktatnak, de maguk is válhatnak hibás imprinterekké kényszerü következményekkel. A kritikus periódusok (perinatalis, pubertalis) biológiailag rögzítettek (és egyre inkább úgy tûnik, hogy a hangsúly ezeken van, és nem az imprinter minőségén), mint a DOHaD is mutatja, és a jóakaratú akalmazás (például gyógyszerek használata a kritikus periódusokban) is visszaüthet. Egyáltalán nem biztos azonban, hogy ez a „visszaütés” evolúciós mértékú hosszú távon is káros, mert nem ismerjük jelenlegi szervezetünk evolúciós funkcionális kialakulását. Lehet, hogy - mint az immunitás esetében, amikor például a pestisjárványok szelektálták az életképesebb (erősebb immunitású) egyedeket, és ezáltal lehetőséget teremtettek a faj rezisztenciájának növekedésére - ez a DOHaDbetegségek esetében is fennáll. A jellemzően negatív hatások mellett szórványosan máris lehet pozitívakat találni, de bármelyik általánosításához még hosszú időnek kell eltelnie. Így a megítélésben, ami egyedi szempontból tragédia, az a faj jövője szempontjából lehet előny [4146]. Az orvos azonban nem a fajt gyógyítja, hanem az egyént, így mindenképpen küzdenie kell a $\mathrm{DOHaD}$ (hormonális imprinting) megnyilvánulásai ellen, amihez a DOHaD lehetőség szerinti felismerése, és ha erre mód nyílik, hatásának megelőzése szükséges.

Anyagi támogatás: A közlemény megírása anyagi támogatásban nem részesült.

A szerző a cikk végleges változatát elolvasta és jóváhagyta.

Érdekeltségek: A szerzőnek nincsenek érdekeltségei.

\section{Irodalom}

[1] Barker DJ, Osmond C. Infant mortality, childhood nutrition, and ischaemic heart disease in England and Wales. Lancet 1986; 137: 1077-1081.

[2] Barker DJ. In utero programming of cardiovascular disease. Theriogenology 2000; 53: 555-574.

[3] Barker DJ, Godfrey KM, Gluckman PD, et al. Fetal nutrition and cardiovascular disease in adult life. Lancet 1993; 341: 938-941.
[4] Barker DJ, Winter PD, Osmond C, et al. Weight in infancy and death from ischemic heart disease. Lancet $1989 ; 2(8663)$ : 577580 .

[5] Barker DJ, Winter PD, Osmond C, et al. Weight gain in infancy and cancer of the ovary. Lancet 1995; 345: 1087-1088.

[6] Phillips DI, Barker DJ, Osmond C. Infant feeding, fetal growth and adult thyroid function. Acta Endocrinol (Copenh). 1993; 129: 134-138.

[7] Csaba G. Phylogeny and ontogeny of hormone receptors: the selection theory of receptor formation and hormonal imprinting. Biol Rev Camb Philos Soc. 1980; 55: 47-63.

[8] Csaba G. The present state in the phylogeny and ontogeny of hormone receptors. Horm Metab Res. 1984; 16: 329-335.

[9] Dickinson H, Moss TJ, Gatford KL, et al. A review of fundamental principles for animal models of DOHaD research: an Australian perspective. J Dev Orig Health Dis. 2016; 7: 449-472.

[10] Csaba G. Does receptor memory exist and is it inherited? [Létezik-e és öröklődik-e a receptor-memória?] Orv Hetil. 1982; 123: 451-455. [Hungarian]

[11] Csaba G, Németh G, Vargha P. Receptor "memory" in Tetrabymena: does it satisfy the general criteria of memory? An experimental study on induction and extinction by retroactive interference in a unicellular organism. Exp Cell Res. 1984; 52: 320-325.

[12] Csaba G. Revaluation of the concept of developmental abnormality. The importance of faulty perinatal imprinting. [A fejlődési rendellenesség fogalmának átértelmezése, a hibás perinatalis imprinting jelentősége.] Orv Hetil 2015; 156: 1120-1127. [Hungarian]

[13] Csaba G. The faulty perinatal hormonal imprinting as functional teratogen. Curr Pediatr Rev. 2016; 12: 222-229.

[14] Csaba G, Inczefi-Gonda Á, Dobozy O. Hormonal imprinting in adults: insulin exposure during regeneration alters later binding capacity of hepatic insulin receptors. Acta Physiol Hung. 1989; 73: 461-464.

[15] Csaba G. Immunoendocrinology: faulty hormonal imprinting in the immune system. Acta Microbiol Immunol Hung. 2014; 61: 89-106.

[16] Csaba G. Effect of endocrine disruptor phytoestrogens on the immune system: present and future. Acta Microbiol Immunol Hung. 2018; 65: 1-14.

[17] Csaba G. The biological basis and clinical significance of hormonal imprinting, an epigenetic process. Clin Epigenetics 2011; 2: 187-196.

[18] Csaba G. Late manifested sequelae of medications in the critical periods of development. The widening of the faulty hormonal imprinting conception. $[\mathrm{Az}$ egyedfejlódés kritikus fázisaiban történő gyógyszeres kezelések késői következményei. A hibás hormonális imprinting koncepciójának kiterjesztése.] Orv Hetil. 2020; 161: 43-49. [Hungarian]

[19] Csaba G. Dangerous faulty perinatal imprinting by medication: review and hypotheses. Clin Obstet Gynecol Reprod Med. 2019; 5: 1-4. Doi: 10.15761/COGRM.1000261.

[20] Tchernitchin AN, Tchernitchin NN, Mena MA, et al. Imprinting: perinatal exposures cause the development of diseases during the adult age. Acta Biol Hung. 1999; 50: 425-440.

[21] Goudochnikov VI. The role of glucocorticoids in aging and agerelated pharmacotherapy. Adv Gerontol. 2011; 24: 48-53.

[22] Tchernitchin AN, Gaete L. Influence of environmental pollutants on human gestation: cause of adult pathologies. [Influencia de contaminantes ambientales en la gestación humana: causante de patologías en el adulto.] Rev Chil Pediatr. 2018; 89: 761765. [Spanish]

[23] Goudochnikov VI. Role of hormones in perinatal and early postnatal development: Possible contribution to programming/ imprinting phenomena. [Роль гормонов щитовидной железы и потребления иода в онтопатогенезе различных заболеваний: акцент на взаимодействиях с глюкокортикоидами и веществами, нарушающими эндокринную регуляцию.] Ontogenez 2015; 46: 285-294. [Russian] 
[24] Ho S-M, Cheong A, Adgent MA, et al. Environmental factors, epigenetics, and developmental origin of reptoductive disorders. Reprod Toxicol. 2017; 68: 85-104.

[25] Dall GV, Britt KL. Estrogen effects on the mammary gland in early and late life and breast cancer risk. Front Oncol. 2017; 7: 110.

[26] De Assis S, Hilakivi-Clarke L. Timing of dietary estrogenic exposures and breast cancer risk. Ann N Y Acad Sci. 2006; 1089: $14-35$.

[27] Delisle H. Foetal programming of nutrition - related chronic diseases. Sante 2002; 12: 56-63. [La programmation foetale des maladies chroniques liées à la nutrition.] [French]

[28] Barker DJ. The origins of the developmental origins theory. J Intern Med. 2007; 261: 412-417.

[29] Hanson M. The inheritance of cardiovascular disease risk. Acta Paediatr. 2019; 108: 1747-1756.

[30] Faa G, Manchia M, Pintus R, et al. Fetal programming of neuropsychiatric disorders. Birth Defects Res C Embryo Today 2016; 108: 207-223.

[31] Barella LF, de Oliveira JC, de Freitas Mathias PZ, et al. Pancreatic islets and their roles in metabolic programming. Nutrition 2014; 30: 373-379.

[32] Grigorenko EL. Brain development: the effect of interventions on children and adolescents. In: Bundy DA, de Silva N, Horton $\mathrm{S}$, et al. (eds.) Child and adolescent health and development. 3rd edition. Chapter 10. The World Bank, Washington, DC, 2018.

[33] Csaba G, Inczefi-Gonda Á. Direct and transgenerational effect of benzpyrene treatment at adolescent age on the uterine estrogen receptor and thymic glucocorticoid receptor of the adult rat. Acta Physiol Hung. 1999; 86: 29-36.

[34] Barker JP, Sultan HY. Fetal programming of human diseases. In: Hansen MA, Spencer JA, Rodeck CH. (eds.) Fetus and neonate: physiology and clinical application. Vol. 3. Cambridge University Press, Cambridge (UK), 1995.

[35] Csaba G., Török O. Influence of insulin and biogenic amines on the division of Chang liver cells after primary exposure (imprinting) and repeated treatments. Cytobios 1991; 66: 153-156.
[36] Nagy SU, Csaba G. Dose dependence of the thyrotropin (TSH) receptor damaging effect of gonadotropin in the newborn rats. Acta Physiol Hung. 1980; 56: 417-420.

[37] Suzuki K. The developing world of DOHaD. J Dev Orig Health Dis. 2018; 9: 266-269

[38] Prusinski L, Al-Hendy A, Yang Q. Developmental exposure to endocrine disrupting chemicals alters the epigenome: identification of reprogrammad targets. Gynecol Obstet Res. 2016; 3: $1-6$.

[39] Csaba G. Thoughts on the cultural evolution of man. Developmental imprinting and transgenerational effect. Riv Biol. 2007; 100: $461-474$

[40] Csaba G. The role of endocrine disruptors in the present and future human endocrine evolution: the ed-exohormone-system. J Transl Sci. 2019; 5: 1-3. Doi: 10.15761/JTS.1000312.

[41] Haugen AC, Schug TT, Collman G, et al. Evolution of DOHaD: the impact of environmental health sciences. J Dev Orig Health Dis. 2015 ; 6: 55-64.

[42] Philips EM, Jaddoe VW, Trasande L. Effects of early exposure to phthalates and bisphenols on cardiometabolic outcomes in pregnancy and childhood. Reprod Toxicol. 2017; 68: 105-118.

[43] DiVall SA. The influence of endocrine disruptors on growth and development of children. Curr Opin Endocrinol Diabetes Obes. 2013; 20: 50-55.

[44] Barouki R, Melén E, Herceg Z, et al. Epigenetics as a mechanism linking developmental exposures to long-term toxicity. Environ Int. 2018; 114: 77-86.

[45] Gutiérrez-Torres DS, Barraza-Villarreal A, Hernandez-Cadena $\mathrm{L}$, et al. Prenatal exposure to endocrine disruptors and cardiometabolic risk in preschoolers: a systematic review based on cohort studies. Ann Glob Health 2018; 84: 239-249.

[46] Csaba G. Hormonal imprinting - the unforeseeable future. [Hormonális imprinting, a kiszámíthatatlan jövő.] Orv Hetil. 2010; 151: 1323-1330. [Hungarian]

(Csaba György dr., e-mail: csagyor@dgci.sote.hu)

\section{"Cogito, ergo sum." (Descartes) (Gondolkodom, tehát vagyok.)}

A cikk a Creative Commons Attribution 4.0 International License (https://creativecommons.org/licenses/by/4.0/) feltételei szerint publikált Open Access közlemény, melynek szellemében a cikk bármilyen médiumban szabadon felhasználható, megosztható és újraközölhető, feltéve, hogy az eredeti szerző és a közlés helye, illetve a CC License linkje és az esetlegesen végrehajtott módosítások feltüntetésre kerülnek. (SID_1) 